\title{
Pseudolamproglena boxshalli sp. n. (Lernaeidae: Lamprogleninae) parasitic on gills of Cyprinion macrostomum (Teleostei: Cyprinidae) from the Tigris River, Iraq
}

\author{
Fatima S. Al-Nasiri ${ }^{1}$, Ju-shey $\mathrm{Ho}^{2}$ and Furhan T. Mhaisen ${ }^{3}$ \\ ${ }^{1}$ Department of Biology, College of Science, University of Tikreet, Tikreet, Iraq; \\ ${ }^{2}$ Department of Biological Sciences, California State University, Long Beach, CA 90840-3702, USA; \\ ${ }^{3}$ Tegnervägen 6B, 64136 Katrineholm, Sweden
}

\begin{abstract}
A new species of lamproglenine copepods, Pseudolamproglena boxshalli sp. n., is described from gills of the cyprinid fish Cyprinion macrostomum Heckel from the Tigris River in Tikreet, north of Baghdad, Iraq. This is the second species of Pseudolamproglena from Iraq and the fourth in the world. It differs from its three congeners mainly in the armature of antennule, maxilla, maxilliped, legs 1-4 and caudal ramus.
\end{abstract}

Keywords: taxonomy, morphology, parasitic Crustacea, Copepoda, teleost fish

Cyprinion macrostomum Heckel is an important fish species in riverine and culture fisheries in Iraq. It belongs to the family Cyprinidae, which contains by far the most species in Iraqi fresh waters, $c a$. $72 \%$ of native fishes (Coad 2010). Sixty-two parasite species have so far been recorded from this fish in Iraq including six species of crustacean parasites (Mhaisen 2012).

According to Mhaisen (2012), among the 21 crustacean species reported from freshwater fishes of Iraq, five species belong to the family Lernaeidae: two of the subfamily Lernaeinae (Lernaea cyprinacea Linnaeus, 1758 and L. oryzophila Monod, 1932) and three of the subfamily Lamprogleninae (Lamproglena chinensis Yü, 1937; L. pulchella von Nordmann, 1832 and Pseudolamproglena annulata Boxshall, 1976).

Members of the subfamily Lamprogleninae are characterized by the absence of the holdfast on their cephalothorax and the possession of a pair of uniseriate egg sacs. Most species are known from females, which are highly modified for a parasitic way of life, whereas their males die soon after mating (Ho 1998).

Members of the genus Pseudolamproglena Boxshall, 1976 are distinguished from those of Lamproglena von Nordmann, 1832 by their distinctive somatic segmentation as well as by the structure and armature of the maxillae and maxillipeds (Boxshall 1976). According to Boxshall and Montú (1997), Pseudolamproglena has a maxilla with a massive inflated proximal segment, distal claw located on the medial margin midway along the segment, whereas Lamproglena has a maxilla with tapering, cylindrical proximal segment bearing typically bifid dis- tal claw. In his cladistic analysis of Lernaeidae, Ho (1998) indicated that endopods of legs 1-4 are two-segmented in Pseudolamproglena but three-segmented in Lamproglena.

The genus Pseudolamproglena was erected by Boxshall (1976) with $P$. annulata from the gills of C. macrostomum from Iraq as the type species and $P$. simplex from the gills of Labeo diplostomus (= Gangana diplostoma Heckel) from India. Kuang (1980) described Mesolamproglena sinilabis from the gills of Sinilabeo dero [= Bangana dero (Hamilton)] from China, which was later transferred to Pseudolamproglena by Kuang and Qian (see Ho 1998).

When examining parasites of fishes captured from the Tigris River in Tikreet, Salah Al-Deen province, we found another species of Pseudolamproglena on the gills of C. macrostomum, which is described in this paper.

\section{MATERIALS AND METHODS}

From July 2009 to June 2010, a total of 84 specimens of Cyprinion macrostomum were collected from the Tigris River in Tikreet ( $\left.34^{\circ} 37^{\prime} \mathrm{N}, 43^{\circ} 41^{\prime} \mathrm{E}\right)$, Salah Al-Deen province, Iraq. The total length of these fish ranged from 11.6 to 28.0 (mean 17.6) $\mathrm{cm}$ and they were identified according to Coad (2010).

In the laboratory, the gills were removed and examined; collected copepods were fixed and stored in $70 \%$ ethanol. They were then cleared in $80 \%$ lactic acid before dissection on a wooden slide (Humes and Gooding 1964). Drawings were made with a drawing tube on an Olympus compound microscope. Copepod body terminology followed Boxshall (1976). Infection parameters (prevalence and intensity of infection) were calculated according to Bush et al. (1997). Scientific names of the fish hosts used in this report follow Froese and Pauly (2012). 


\section{RESULTS}

Pseudolamproglena boxshalli sp. $\mathrm{n}$.

Fig. 1

Female. Body (Fig. 1B) cylindrical and indistinctly segmented. Total body length ranged from 2.24 to $2.60 \mathrm{~mm}$, with a mean of $2.37 \mathrm{~mm}$. Cephalothorax (Fig. $1 \mathrm{~A}, \mathrm{C}, \mathrm{D})$ broad, concave in dorsal surface and comprising $15-18 \%$ of total body length. Anterior portion of first pedigerous somite incorporated into cephalothorax; posterior portion free, rounded dorsally and narrower than both cephalothorax and second pedigerous somite. Second to fourth pedigerous somites separated by intersegmental sutures, subdivided into anterior and posterior portions by a transverse groove, equal in width. Thoracic legs located anterior to groove. Thoracic somites increasing in size posteriorly.

Genital complex small, narrower than fourth pedigerous somite and with a ventrolateral egg sac attachment area. Abdomen elongated, narrower than fourth thoracic somite and genital complex, consisting of two distinctly divided somites. Posterior margin of anal somite bilobate, bearing medially directed caudal rami (Fig. 1E). Egg sac (Fig. 1F) uniseriate, containing 19 or 20 eggs (based on two specimens).

Colour of live specimens light brown during winter and dark brown during summer, with two integrated orange spots (nauplius eye?) located medially on dorsal surface of cephalothorax. Immature eggs light brown and mature ones hyaline.

Antennule (Fig. 1G) situated on ventral surface near anterior margin of cephalothorax, directed posterolaterally, two-segmented. Large proximal (basal) segment bearing eight setae and two aesthetasc-like elements on their margin and distal (apical) segment armed with three setae and two aesthetasc-like elements.

Antenna (Fig. 1H), situated lateral to transverse ridge on ventral surface of cephalothorax, anterior to trilobate structure, directed posteriorly, indistinctly two-segmented with five setae on distal segment.

Oral region (Fig. 1A,D) occupied by large trilobate structure, representing labrum. Transverse ridge present on ventral surface of cephalothorax anterior to trilobate structure. Maxillule absent. Maxilla (Fig. 1I) massive and two-segmented; proximal segment broad, inflated distal segment armed with robust, curved claw on medial surface. Maxilliped (Fig. 1J) indistinctly three-segmented, proximal segment connected by transverse ridge of tissue on ventral surface, cylindrical middle segment elongate, terminal segment armed with nine setae arranged in three rows on medial surface.

Thoracic legs 1-4 (Fig. 1K-N) similar, biramous. Sympod projecting from body surface. Endopod twosegmented, exopod three-segmented. Leg 1 (Fig. 1K) sympod with serrated distal margin; endopod armed with
A

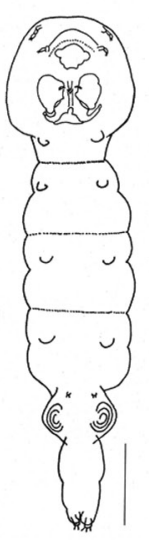

B
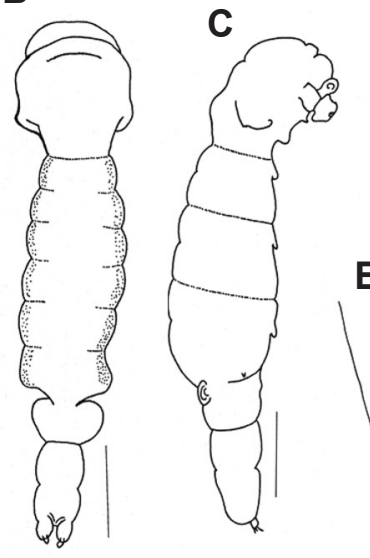

D

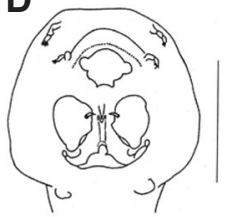

E
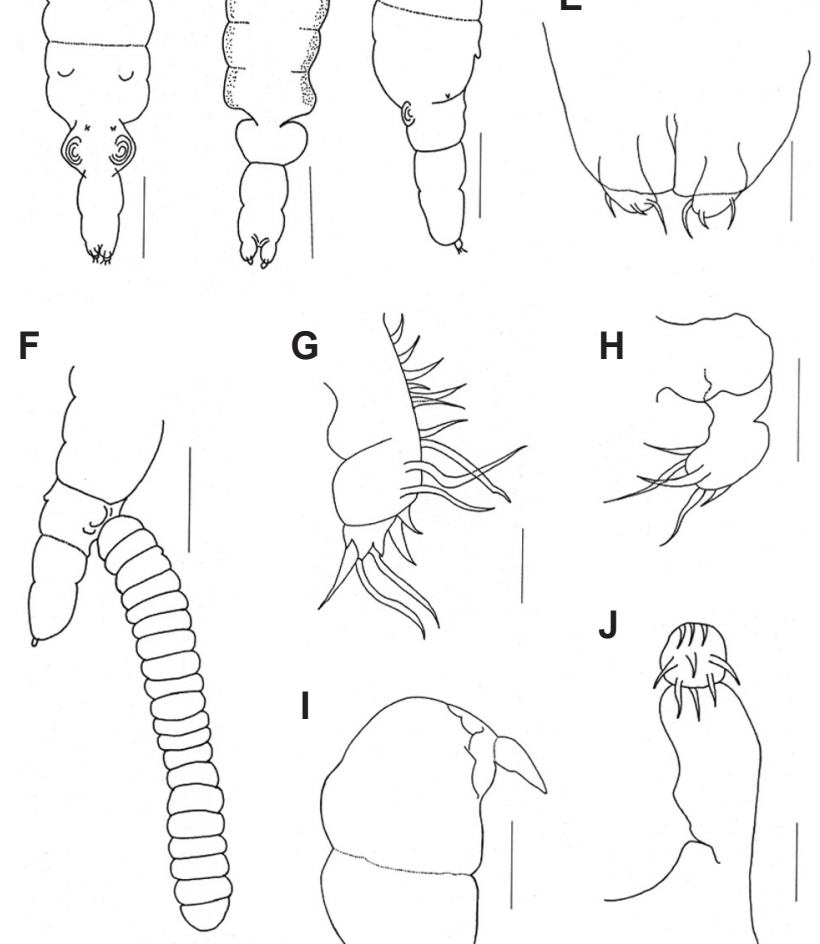

I
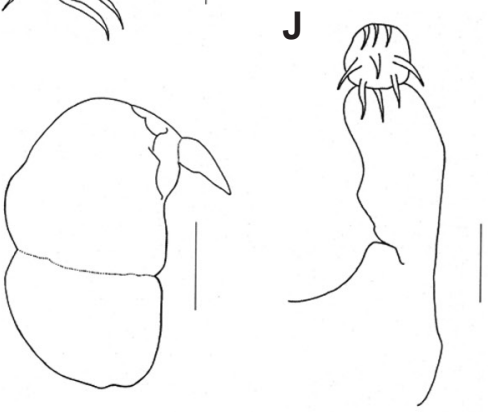

$\mathrm{K}$
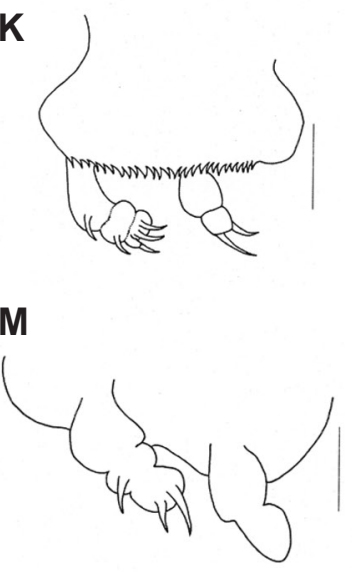

$\mathbf{N}$
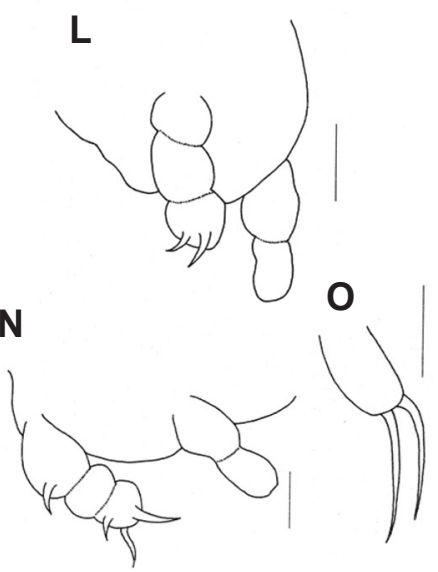

Fig. 1. Pseudolamproglena boxshalli sp. n., paratype female. A - habitus, ventral; B - habitus, dorsal; C - habitus, lateral; $\mathrm{D}$ - cephalothorax, ventral; $\mathrm{E}$ - caudal rami; $\mathrm{F}$ - posterior portion of body, lateral; $\mathrm{G}$ - antennule; $\mathrm{H}$ - antenna; I - maxilla; J - maxilliped; $\mathrm{K}-\operatorname{leg} 1 ; \mathrm{L}-\operatorname{leg} 2 ; \mathrm{M}-\operatorname{leg} 3 ; \mathrm{N}-\operatorname{leg} 4 ; \mathrm{O}-\operatorname{leg} 5$. Scale-bars: A, C, D $=0.3 \mathrm{~mm}$; B, F $=0.4 \mathrm{~mm}$; E, I $=0.05 \mathrm{~mm}$; $\mathrm{G}, \mathrm{H}, \mathrm{J}-\mathrm{O}=0.02 \mathrm{~mm}$. 
two unequal setae at tip of distal segment; exopod with three terminal setae and one lateral seta on both middle and proximal segments. Leg 2 (Fig. 1L) exopod armed with two setae on distal segment. Leg 3 (Fig. 1M) exopod armed with two unequal setae on distal segment and one lateral seta on second segment. Leg 4 (Fig. 1N) exopod armed with three setae on distal segment and one lateral seta on proximal segment. Leg 5 (Fig. 1O) positioned anteriorly on ventral surface of genital complex (see Fig. 1A), comprising a simple process bearing two apical setae.

Caudal ramus (Fig. 1E) armed with three setae, one on lateral margin, one on medial margin and one at posterolateral corner.

Male: Unknown

Type host: Cyprinion macrostomum Heckel (Teleostei: Cyprinidae).

Site of infection: Gills.

Type 1 oc ality: Tigris River in Tikreet $\left(34^{\circ} 37^{\prime} \mathrm{N}, 43^{\circ} 41^{\prime} \mathrm{E}\right)$, Salah Al-Deen province, Iraq.

Prevalence of infection: $5 \%(n=84)$.

Intensity of infection: 1-5 with a mean of 2 parasites per infected fish.

Etymology: The new species is named in honour of Geoff A. Boxshall, who erected the genus Pseudolamproglena.

Specimens deposited: Four females removed from the gills, collected on 23 July 2009. Holotype (USNM 1180552) and 3 paratypes (USNM 1180553) have been deposited in the collections of the National Museum of Natural History, Smithsonian Institution, Washington, D.C., USA.

Remarks. The generic assignment of $P$. boxshalli sp. $\mathrm{n}$. is in agreement with the diagnostic features of the genus Pseudolamproglena erected by Boxshall (1976) on the basis of both $P$. annulata from Iraq and $P$. simplex from India.

\section{DISCUSSION}

Pseudolamproglena sinilabis seems to be the longest of all the species of the genus, with the total length of 2.93-3.67 mm (Kuang 1980) compared to P. annulata less than $2.2 \mathrm{~mm}$ (Boxshall 1976), P. simplex - less than
$2.45 \mathrm{~mm}$ (Boxshall 1976), and P. boxshalli - less than $2.6 \mathrm{~mm}$. The new species is also distinguishable from $P$. sinilabis in its armature with five (instead of eight) setae on the antenna, bearing three-segmented (instead of two-segmented) exopods on all four pairs of legs, and additionally having a caudal ramus tipped with three (instead of six) setae. Furthermore, P. sinilabis does not have maxillipeds (Kuang, 1980).

Pseudolamproglena boxshalli is similar to P. annulata in its distinctly segmented body, the absence of the maxillule and the presence of the large trilobate structure in the oral region. Nevertheless, it differs from P. annulata in the armature of the antennules (eight setae and two aesthetasc-like elements on the proximal segment of antennules of $P$. boxshalli versus 14 setae and one aesthetasc-like element on that of $P$. annulata), maxillipeds (nine setae on the distal segment of the maxillipeds of $P$. boxshalli versus only one in $P$. annulata), leg 1 (with serrated distal margin of sympod versus smooth margin in $P$. annulata; five setae on the exopod compared to two setae with one spine in $P$. annulata), legs 1-4 (no setae on sympod compared to one in $P$. annulata), legs 2-4 (two, three and four setae, respectively, on the exopod versus only one spine in P. annulata), and caudal rami (three setae on caudal rami of $P$. boxshalli compared to four in P. annulata).

Unlike $P$. annulata, both $P$. simplex and $P$. boxshalli have antennae. However, $P$. simplex differs from $P$. boxshalli by having a less distinctly segmented body, the presence of the maxillules, a hemispheric lobe in the oral region as well as differences in the armature of the maxillipeds, antennules, legs $1-4$ and the caudal rami. Two setae are present on the distal segment of the maxilliped of $P$. simplex in comparison with nine setae on that of $P$. boxshalli, 11 setae on the proximal segment of the antennule of $P$. simplex versus eight setae and two aesthetasc-like elements on that of $P$. boxshalli, and six setae on the caudal rami of $P$. simplex compared to only three on that of P. boxshalli.

\section{REFERENCES}

Boxshall G.A. 1976: A new genus and two new species of copepod parasitic on freshwater fishes. Bull. Br. Mus. Nat. Hist. 30: 209-215.

Boxshall G.A., Montú M.A. 1997: Copepods parasitic on Brazilian coastal fishes: a handbook. Nauplius, Rio Grande 5: $1-225$.

Bush A.O., Lafferty K.D., Lotz J.M., Shostak A.W. 1997: Parasitology meets ecology on its own terms: Margolis et al. revisited. J. Parasitol. 83: 575-583.

CoAd B.W. 2010: Freshwater Fishes of Iraq. Pensoft Publ., Moscow, 274 pp. + 16 Plts.
Froese R., Pauly E. (Eds.) 2012: FishBase. World Wide Web electronic publication, www.fishbase.org, version 06/2012.

Ho J.-S. 1998: Cladistics of the Lernaeidae (Cyclopoida), a major family of freshwater fish parasites. J. Mar. Syst. 15: 177-183.

Humes A.G., Gooding R.U. 1964: A method for studying the external anatomy of copepods. Crustaceana 6: 238-240.

KuANG P.R. 1980: A new genus of Lernaeidae (parasitic copepods) and its relation to affined genera. Acta Zootaxon. Sin. 5: 124-128. (In Chinese with English summary.)

Mhaisen F.T. 2012: Index-catalogue of parasites and disease agents of fishes of Iraq. Unpublished manuscript. Available upon request from mhaisenft@yahoo.co.uk. 